\title{
Knowledge and Attitudes of Students toward Fast Food in Assiut University
}

\author{
Asmaa H. Mahmoud ${ }^{1}$, Neama M. Mohamed ${ }^{2}$ \& Shimaa A. El-wardany ${ }^{3}$ \\ ${ }^{1 .}$ High Qualified Nurse at Technical secondary school of Nursing for Girls at Sahel Saleem, Egypt. \\ 2. Professor of Community Health Nursing, Faculty of Nursing, Assiut University. Egypt. \\ ${ }^{33}$ Assistant Professor of Community Health Nursing, Faculty of Nursing, Assiut University. Egypt.
}

\begin{abstract}
Background: Consumption of fast foods has become a hallmark of modern urban and semi- urban life style that have many adverse effects on health. Aim: To assess knowledge and attitudes of students toward fast food in Assiut university. Subject and Method: a descriptive cross sectional research design was used. The study conducted at four faculties of Assiut University among 1217 students who were selected by simple random sample. Tools: In this study utilized three tools for gathering data: the first tool; a structured self-administered questionnaire which included socio-demographic characteristic scale, knowledge and consumption of fast food, the second tool; attitude toward fast food and the last tool; anthropometric measurements. Results: It was found that $63.3 \%$ of studied students were males and $52.9 \%$ of them with middle socioeconomic class. Also the study cleared that $91.9 \%$ from students having fast food, whereas a positive correlation between total score of student's knowledge and attitude toward fast food with statistical significant difference between having fast food, knowledge and attitude. Conclusions: the outcome of present study concluded that lack of students' knowledge and had positive attitude about fast food. Recommendation: Periodic health education programs regarding effects of fast food on health.
\end{abstract}

\section{Keywords: Attitude, Fast food \& Knowledge.}

\section{Introduction}

Healthy diet is a diet that helps to maintain or improve overall health and provides the body with essential nutrition such as fluid, macronutrients, micronutrients, and adequate calories The nutrients are chemical substances that are present in the food. The important nutrients are proteins, fats, carbohydrates, vitamins, minerals and water. Foods contain various nutrients in different proportions, depending on the relative concentration of various nutrients foods that serves many functions in the body. (Barrett et al., 2020).

Fast food is refers to food sold in restaurant or store with preheated or precooked components, and served to the customer in a package method for takeout or take-away; (Nipun et al., 2017). Fast food simply means a high calorie food which lacks in micro-nutrients such as vitamins (A and C), minerals, or amino acids, and fiber. These foods don't contain the nutrients that body needs to remain healthy. Hence, it is poor nutritional value and considered unhealthy because contain colors that are indigestible, carcinogenic and harmful to the body (Palos Lucio et al., 2020).

Few dietary guidelines adherence studies have been shown in Eastern Mediterranean countries, for example, in Saudi Arabia, Kuwait, Iran and Lebanon. No studies of diet quality and/or dietary guidelines adherence seem to have been conducted in Egypt and research that emphases on young adult university people is sparse. Moreover there are studies about socioeconomic determinants of eating pattern of adolescent students in Mansoura, Egypt (El-Gilany \& Elkhawaga, 2012) which cleared that $34.1 \%$ of students practiced many faulty meal patterns and ate snacks daily. Studies in Arab countries, concentrated on consumer behavior in relation to fast food, are deficient so researchers touches on topic to identify knowledge and attitude of university students (Musaiger et al.,2013).

Many youngsters have adjusted to changing fastfood culture. These changes are accompanied by dramatic transformations in dietary patterns and increase in the consumption of processed foods such as hamburgers, cheeseburgers, deep-fried chicken, deep-fried potatoes/French fries, pizza etc. Fast-food consumption seems to be linked closely with softdrink which have high fat levels and decreasing consumption of fruits and vegetables are the factors that related to health problems as diabetes, hypertension, obesity and coronary artery disease. (Kumari \& Kumari ,2020).

Eating behaviors and food choices are influenced by nationality, culture, community, family, and individual food choice. Most of People like to eat fast food for various reasons containing price, save time, influence of media, peer pressure, availability, quick service and the taste of the food (Monterrosa et al., 2020). 
Community health Nurses deal with people in many settings and dress many hats while conducting dayto-day practice. The focus of nurse includes not only the individual, but also the family and the community; meeting these multiple needs requires multiple roles .Community health nurse encourage the students to take right food for maintaining health, provide sufficient information about healthy food and hazards of fast food to take necessary health care decision and promote community awareness of significant health problems. (Egbujie et al., 2018).

\section{Significance of the study}

The college students; representative the young age population of community; for different reasons are predisposed to eat unhealthy foods and to have bad health habits during their college years which might affect their wellbeing and increase the risk of diabetes ,obesity and coronary heart disease ( AlQahtani, 2016).

Study about adherence to recommended dietary guidelines and the relationships with the importance of eating healthy in Egyptian university students which cleared that $34.1 \%$ of students practiced many faulty meal patterns and ate snacks daily.(El Ansari \& Samara, 2018).

So the present study was conducted to assess knowledge and attitude of university students regarding fast food at Assuit University.

Aim of study:

To assess knowledge and attitudes of university students toward fast food

\section{Research question:}

What are the student's knowledge and attitudes about fast food?

\section{Subject and Method \\ Research design:}

A descriptive cross-sectional research design was used.

Setting: Assiut University includes (18) faculties divided into (12) practical colleges and (6) theoretical colleges; this study was conducted at (4) faculties which selected randomly includes two practical faculties (faculty of pharmacy and faculty of computer \& information) and two theoretical faculties (faculty of social services and faculty of Education).

\section{Sampling size:}

The total number of students in a selected faculties were 16716 students, by applying software EPI/info, version 3, 3 with 99, 9\% confidence interval (CI), the sample size estimated was 1017 students .To compensate the drop outs; $(20 \%)$ was added to the sample size; the final sample size were 1217 . The following table clears the name of faculties from which the sample selected and the number of students in each faculty: Table (1)

\begin{tabular}{|r|c|c|c|}
\hline Faculty & $\begin{array}{c}\text { Number } \\
\text { of } \\
\text { students }\end{array}$ & $\begin{array}{c}\text { Sample } \\
\text { size }\end{array}$ & Percent \\
\hline $\begin{array}{r}\text { Faculty } \\
\text { ofEducation }\end{array}$ & 7852 & 572 & $47 \%$ \\
\hline $\begin{array}{r}\text { Faculty of } \\
\text { social service }\end{array}$ & 4408 & 321 & $26 \%$ \\
\hline $\begin{array}{r}\text { Faculty of } \\
\text { pharmacy }\end{array}$ & 3231 & 235 & $19.3 \%$ \\
\hline $\begin{array}{r}\text { Faculty of } \\
\text { computer and } \\
\text { information }\end{array}$ & 1225 & 89 & $7.3 \%$ \\
\hline Total & $\mathbf{1 6 7 1 6}$ & $\mathbf{1 2 1 7}$ & $\mathbf{1 0 0 \%}$ \\
\hline
\end{tabular}

NB: - percent of sample according the actually percent from total number of students.

Sampling technique: - multistage random sample was utilized in the present study which contained within Simple random sample to select the previous faculties which mentioned above; the names of facilities (practical and theoretical colleges), each of them, are placed in a separate plate, and then the colleges are chosen randomly. Also systematic random sample used for selected the students whereas the researcher was taken the student affairs lists from each faculty to select the students.

To determine the sample for each faculty, the total number of students in the college is divided by the total number of students in the university giving us the percentage of students from each college.

\section{Tools of the study:-}

The following tools were utilized by the researcher and piloted to collect data:

Tool I: A Structured self -administered questionnaire it was developed by the researchers based on relevant literature to collect the needed data; this included three parts:

Part (1): Socio-demographic characteristics which developed by (Abdeltwab,2012) it included: name of faculty, age, gender, , parents education and occupation, residence, type of housing and family income.

Part (2): students' knowledge toward fast food: (7)questions it included the following items: definition of healthy food, definition of fast food, reasons, types, appearance of any symptoms after eating it and effect on health and most category eating fast food with them .

Scoring system of knowledge: The total scores of knowledge was (18) points; a correct response take one grade and the incorrect take zero. The scores of items were summed and then converted into 
percentage. Knowledge was considered: Poor, if the score was less than $50 \%$, fair, if the score was (5070) $\%$ and good, if the score more than $70 \%$ (Musaiger et al., 2013).

Part (3): fast food consumption: It included (7) questions about fast food such as: having fast food, No. of fast food meals per week, types of fast food eaten, reasons for having fast food, ready to stay without fast food, reasons and People who eat fast food with them.

Tool II:

Students Attitude for fast food developed by (Yahya \& Zafar.,2013 \& Abraham et al.,2016 ) To assess students attitudes regarding fast food; it included (15) statement the responses were based on 5 points likert scale ranging from ( strongly disagree 1, disagree 2 , neutral 3 , agree 4 and strongly agree 5 for positive statements and reversed for negative statements.

Scoring system for attitude toward fast food:

The grades for each item were summed and then converted into a percent score. Student attitude was considered positive if the score was $\geq 60 \%$ and negative attitude if the score was $<60 \%$. (Yahya \&Zafar.,2013 \&Abraham et al.,2016) .

Tool III:

It included anthropometric measurements: weight, height and calculate Body mass index (BMI) is calculated after measure weight and height, to calculate it divided weight in $\mathrm{kg}$ by square height in meter $\left(\mathrm{kg} / \mathrm{m}^{2}\right)$$$
\frac{B M I=\text { weight }(\mathrm{kg})}{\text { height }(\mathrm{m}) 2}
$$

Categories of BMI: Lastly the results compared by plotted growth chart according to the World Health Organization (WHO):

Underweight: BMI <18.5 kg.m ${ }^{2}$, Normal: BMI < $25 \mathrm{~kg}$, Overweight: BMI of $\geq 25 \mathrm{~kg} \cdot \mathrm{m}^{2}$ and Obese: BMI $\geq 30$ kg.m ${ }^{2}$ (Mackenbach \& Charreire., 2018).

Validity of tools:

The face validity: the tools were tested by jury of 5 specialists in the field of community health nursing at Assuit University and according to their opinions the necessary modification was done.

\section{Reliability of tools:}

To evaluate the students' attitude toward fast food scale tool II reliability; was analyzed by Cronbach's alpha to measure reliability about 0.830 .
Methodology:-

Administrative design:

Before conducting the study, an official permission letter was obtained from the dean of the faculty of nursing, Assiut University, to vice of university president for education and student's affairs of Assiut University. This letter included a permission to perform the study and explained the nature and purpose of the study.

\section{Ethical consideration:}

The researchers clarified the purpose and nature of the study for students. The student has the right to agree or disagree on participation in the study ,consent to share in the study was secured orally from every student and informed that the information obtained would be confidential and used only for the purpose of the study, during data collection privacy was being considered and written consents were obtained from the Deans of the Colleges that are agreeable to contribute in the present study after explaining the nature and aim of the study.

\section{Operational design}

Pilot Study:

It was applied on $10 \%$ of students (122) which involved in the study sample, for non-existing modifications. It is purpose to assess the feasibility of the study and clarity of tools for gathering data. It also helped to estimate the time needed for filling the sheet.

Data collection Phase:

- Data was gathered by the researchers, in the period from the mid of February to the end of April, 2017, the researchers took two days in each week, 55-65 questionnaires per day. The researchers introduced themself to the Dean of the College at each selected faculties, and reminded them of the nature and purpose of the study. Then, the researchers asked them to take a copy of the study scheduled grades of faculties.

- The researchers were taken oral permission from the teaching staff members who were responsible for the preferred lectures or sections depending on their persuasion and the nature of each faculty, and then the researchers asked them about ideal time for data collection, either in the first or last part of the selected lectures or sections.

- Researchers introduced themself to the students and explained the purpose and nature of the study and explained the main parts of the questionnaire. After that, the researchers distributed the questionnaire to the students .Students were asked to complete the questionnaire and during this period the 
researchers explained any difficulty in the questions .

- Filling the questionnaire and measuring weight and height took 20-25 minutes by students and after completing that the researchers collected the questionnaires with paying careful attention to incomplete answers to ask students to complete them. Finally, the researchers thanked the students and teaching staff for their cooperation.
Statistical analysis:

Data obtained from the study were reviewed, prepared for computer entry ,coded ,analyzed and tabulated .Descriptive statistics (i.e., number, percentage, mean + standard deviation) were done by Statistical Package for Social Science (SPSS) software; version 22. The data presented by Chisquare test used to compare between qualitative variables. Pearson's correlation used to see link among different variables .it is considered statistically significant when P-values were less than $0.05(\mathrm{P}<0.05)$.

Results:

Table 1: Socio-demographic characteristics distribution among studied students at Assiut University, 2017

\begin{tabular}{|c|c|c|}
\hline Items & No. $=(1217)$ & $\%$ \\
\hline \multicolumn{3}{|l|}{ Faculty: } \\
\hline Faculty of Education & 572 & 47.0 \\
\hline Faculty of Social Services & 321 & 26.4 \\
\hline Faculty of Pharmacy & 235 & 19.3 \\
\hline Faculty of Computer and Information & 89 & 7.3 \\
\hline \multicolumn{3}{|l|}{ Age: (years) } \\
\hline $18-$ & 459 & 37.7 \\
\hline $20-$ & 610 & 50.1 \\
\hline More than 22 & 148 & 12.2 \\
\hline Mean \pm SD (Range) & \multicolumn{2}{|c|}{$20.97 \pm 1.14(18.0-25.0)$} \\
\hline \multicolumn{3}{|l|}{ Sex: } \\
\hline Male & 770 & 63.3 \\
\hline Female & 447 & 36.7 \\
\hline \multicolumn{3}{|l|}{ Father education: } \\
\hline Illiterate & 106 & 8.7 \\
\hline Read \& write & 66 & 5.4 \\
\hline Basic education & 162 & 13.3 \\
\hline Secondary & 342 & 28.1 \\
\hline University and Postgraduate & 541 & 44.4 \\
\hline \multicolumn{3}{|l|}{ Mother education: } \\
\hline Illiterate & 284 & 23.3 \\
\hline Read \& write & 89 & 7.3 \\
\hline Basic education(primary and preparatory) & 203 & 16.6 \\
\hline Secondary & 302 & 24.8 \\
\hline University and Postgraduate & 339 & 27.9 \\
\hline \multicolumn{3}{|l|}{ Father occupation: } \\
\hline Employee & 608 & 50.0 \\
\hline Farmer & 185 & 15.2 \\
\hline Free business & 180 & 14.8 \\
\hline Skilled worker & 234 & 19.2 \\
\hline Dead & 10 & 0.8 \\
\hline \multicolumn{3}{|l|}{ Mother occupation: } \\
\hline Working & 332 & 27.3 \\
\hline Housewife & 885 & 72.7 \\
\hline \multicolumn{3}{|l|}{ Residence: } \\
\hline Rural & 743 & 61.1 \\
\hline Urban & 474 & 38.9 \\
\hline
\end{tabular}




\begin{tabular}{|l|c|c|}
\hline \multicolumn{1}{|c|}{ Items } & No.=( 1217) & \% \\
\hline Type of housing: & & 6.2 \\
\hline Rent & 75 & 93.8 \\
\hline Owned & 1142 & 2.4 \\
\hline Family income: & & 3.9 \\
\hline$<300$ pounds & 29 & 11.7 \\
\hline $300-<600$ pounds & 48 & 41.5 \\
\hline $600-<1000$ pounds & 142 & 30.4 \\
\hline $1000-<1800$ pounds & 505 & 10.1 \\
\hline $1800-<4000$ pounds & 370 & 24.9 \\
\hline$\geq 4000$ pounds & 123 & 52.9 \\
\hline Socioeconomic class: & & 22.2 \\
\hline Low & 303 & \\
\hline Middle & 644 & 270 \\
\hline High & & \\
\hline
\end{tabular}

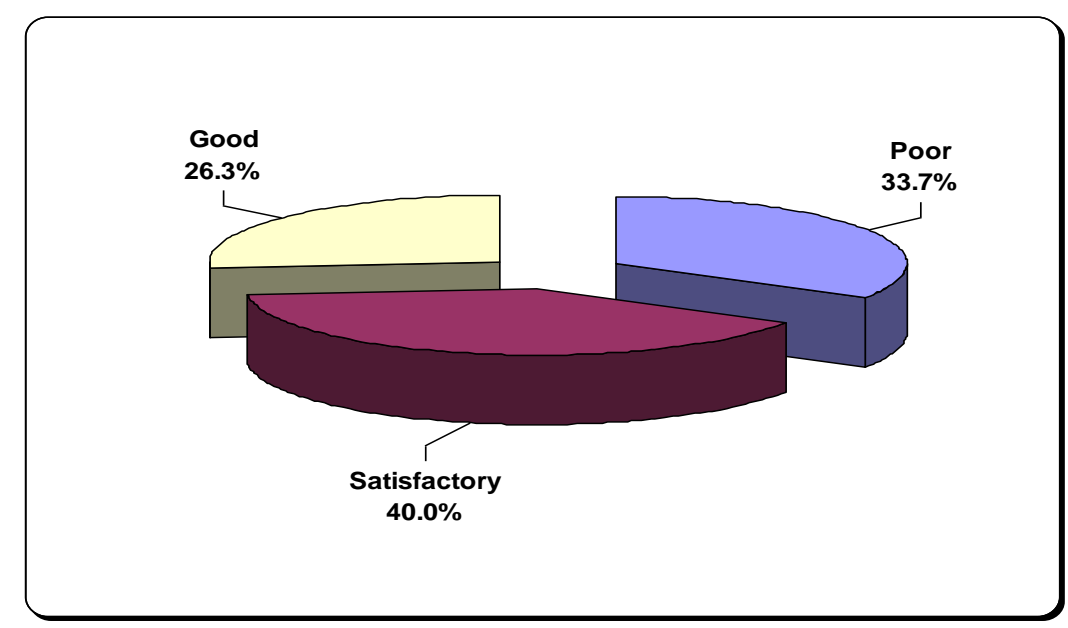

Figure (1): Total score of studied sample knowledge regarding fast food at Assuit University, 2017

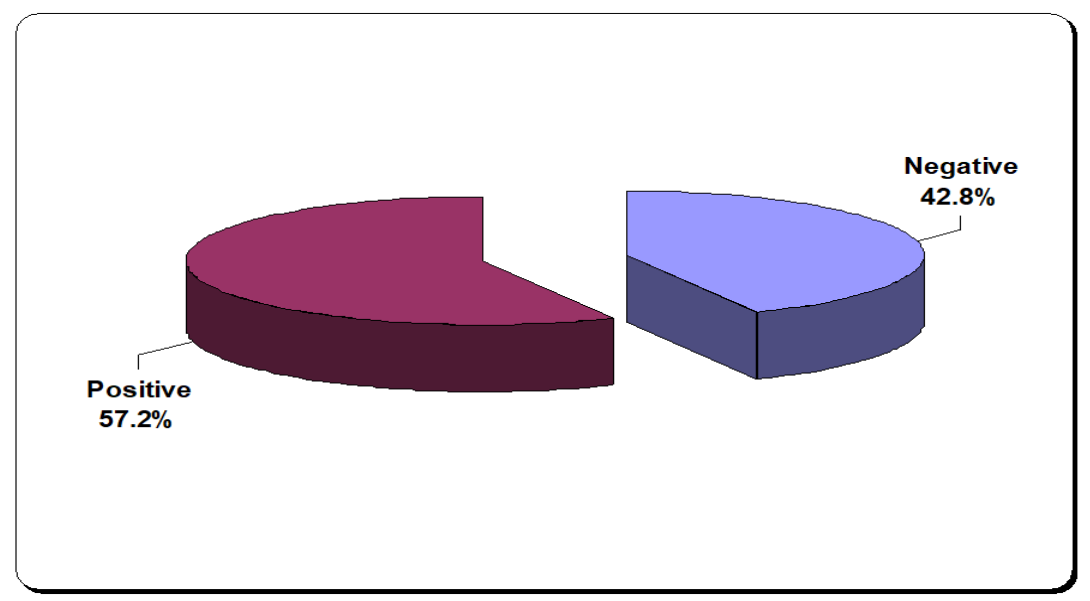

Figure (2): Total score of studied sample attitude regarding fast food at Assuit University, 2017 


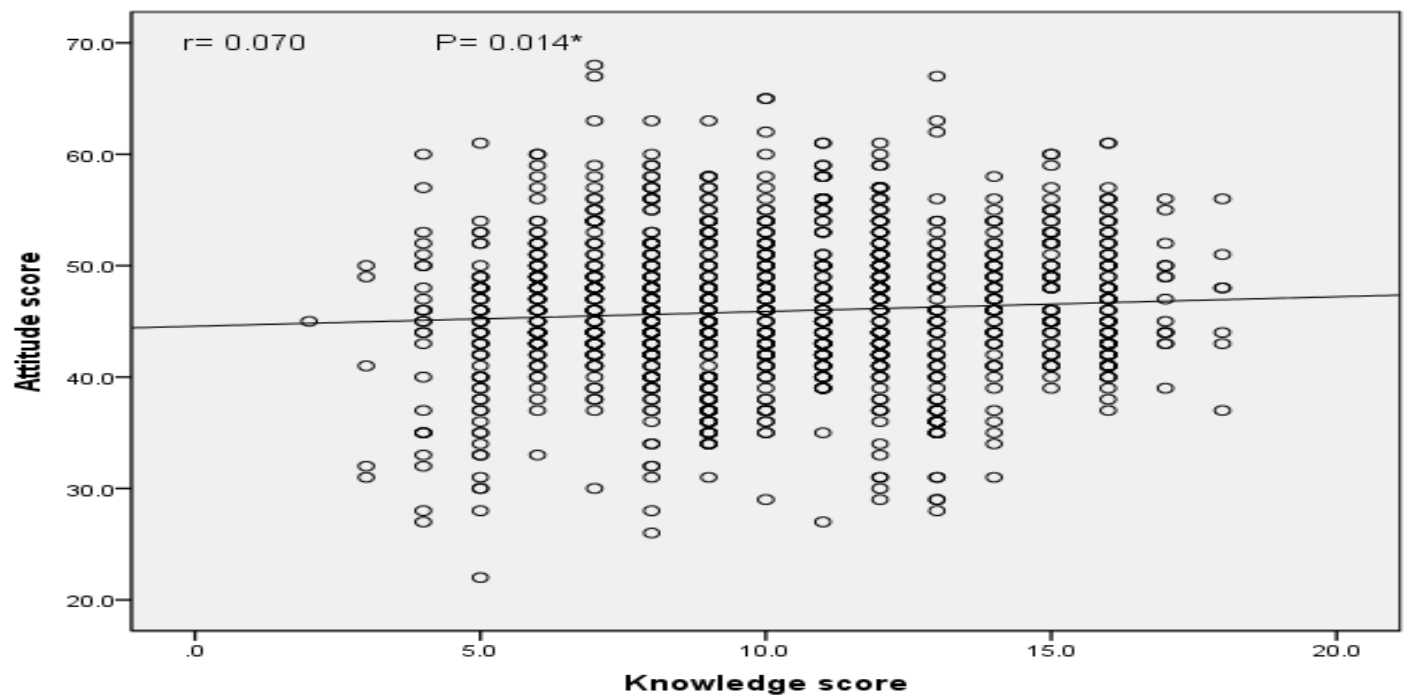

Figure (3): Correlation between the score of studied sample knowledge and their attitude toward fast food at Assuit University, 2017

Table (2): Distribution of fast food consumption among studied sample at Assuit University, 2017

\begin{tabular}{|c|c|c|}
\hline Items & No. $=(1217)$ & $\%$ \\
\hline \multicolumn{3}{|l|}{ Having fast food: } \\
\hline Yes & 1118 & 91.9 \\
\hline No & 99 & 8.1 \\
\hline \multicolumn{3}{|c|}{ No. of fast food meals per week: $(n=1118)$} \\
\hline $1-3$ & 438 & 39.2 \\
\hline $4-6$ & 422 & 37.7 \\
\hline$>6$ & 258 & 23.1 \\
\hline \multicolumn{3}{|c|}{ Most common types of fast food eaten: } \\
\hline Burger & 363 & 32.4 \\
\hline Hot dog & 290 & 25.9 \\
\hline Fried potato & 670 & 59.9 \\
\hline Shawarma & 385 & 34.4 \\
\hline The pizza & 665 & 59.4 \\
\hline Grills & 432 & 38.6 \\
\hline Don't know & 74 & 6.6 \\
\hline \multicolumn{3}{|l|}{ Reasons for having fast food : } \\
\hline 1-It is tasty. & 520 & 46.5 \\
\hline 2-Save time. & 780 & 69.8 \\
\hline 3-Inexpensive. & 200 & 17.9 \\
\hline 4-Easy to get. & 135 & 12.1 \\
\hline \multicolumn{3}{|l|}{ Ready to stay without fast food: } \\
\hline Yes & 304 & 27.1 \\
\hline No & 814 & 72.8 \\
\hline \multicolumn{3}{|l|}{ Reason:(n=304) } \\
\hline 1-Un healthy fast food & 244 & 80.3 \\
\hline 2-fast food Contains a lot of fat & 86 & 28.2 \\
\hline 3-fast food cause obesity & 204 & 67.1 \\
\hline \multicolumn{3}{|c|}{ People who eat fast food with students: } \\
\hline their Family & 93 & 8.3 \\
\hline their Friends & 987 & 88.3 \\
\hline Both & 38 & 3.4 \\
\hline
\end{tabular}

(\#)More than one answer was allowed. 
Table (3): Relationship between the studied sample knowledge, attitude and body mass index regarding to their fast food intake in Assuit University, 2017

\begin{tabular}{|c|c|c|c|c|c|c|}
\hline \multirow{3}{*}{ Items } & \multicolumn{4}{|c|}{ Having fast food } & \multirow{3}{*}{$\mathbf{X}^{2}$} & \multirow{3}{*}{ P-value } \\
\hline & \multicolumn{2}{|c|}{ Yes } & \multicolumn{2}{|c|}{ No } & & \\
\hline & No. & $\%$ & No. & $\%$ & & \\
\hline Knowledge score: & & & & & \multirow{4}{*}{40.44} & \multirow{4}{*}{$0.000^{*}$} \\
\hline Poor & 353 & 86.1 & 57 & 13.9 & & \\
\hline Fair & 448 & 92.0 & 39 & 8.0 & & \\
\hline Good & 317 & 99.1 & 3 & 0.9 & & \\
\hline \multicolumn{5}{|l|}{ Attitude level: } & \multirow{3}{*}{18.66} & \multirow{3}{*}{$0.000 *$} \\
\hline Negative & 499 & 95.8 & 22 & 4.2 & & \\
\hline Positive & 619 & 88.9 & 77 & 11.1 & & \\
\hline \multicolumn{5}{|l|}{ BMI: } & \multirow{4}{*}{2.34} & \multirow{4}{*}{0.310} \\
\hline Underweight & 27 & 93.1 & 2 & 6.9 & & \\
\hline Normal & 593 & 92.9 & 45 & 7.1 & & \\
\hline Overweight/ obese & 498 & 90.5 & 52 & 9.5 & & \\
\hline
\end{tabular}

* Statistical significance difference by $p$ value $<0.05$.

Table (4): Relationship between the studied sample knowledge, attitude and body mass index (BMI) regarding to fast food intake per week in Assuit University, 2017

\begin{tabular}{|c|c|c|c|c|c|c|c|c|}
\hline \multirow{3}{*}{ Items } & \multicolumn{6}{|c|}{ No. of fast food meals per week } & \multirow{3}{*}{$\mathbf{X}^{2}$} & \multirow{3}{*}{ P-value } \\
\hline & \multicolumn{2}{|c|}{$1-3$} & \multicolumn{2}{|c|}{$4-6$} & \multicolumn{2}{|c|}{$>6$} & & \\
\hline & No. & $\%$ & No. & $\%$ & No. & $\%$ & & \\
\hline Knowledge level: & & & & & & & \multirow{4}{*}{21.38} & \multirow{4}{*}{$0.000^{*}$} \\
\hline Poor & 160 & 45.3 & 134 & 38.0 & 59 & 16.7 & & \\
\hline Satisfactory & 170 & 37.9 & 177 & 39.5 & 101 & 22.5 & & \\
\hline Good & 108 & 34.1 & 111 & 35.0 & 98 & 30.9 & & \\
\hline \multicolumn{7}{|l|}{ Attitude level: } & \multirow{3}{*}{57.45} & \multirow{3}{*}{$0.000^{*}$} \\
\hline Negative & 149 & 29.9 & 186 & 37.3 & 164 & 32.9 & & \\
\hline Positive & 289 & 46.7 & 236 & 38.1 & 94 & 15.2 & & \\
\hline \multicolumn{7}{|l|}{ BMI: } & \multirow[t]{4}{*}{4.57} & \multirow[t]{4}{*}{0.334} \\
\hline Underweight & 12 & 44.4 & 9 & 33.3 & 6 & 22.2 & & \\
\hline Normal & 227 & 38.3 & 215 & 36.3 & 151 & 25.5 & & \\
\hline Overweight/ obese & 199 & 40.0 & 198 & 39.8 & 101 & 20.3 & & \\
\hline
\end{tabular}

* Statistical significance difference by p value $<0.05$.

Table (1): Presents socio-demographic characteristics distribution among studied students at Assuit University; which found that 50, $1 \%$ of students' aged from 20 - years old while $12.2 \%$ of them aged more than 22 and $63.3 \%$ were male. According to students' parents education $44.4 \%$ of fathers and $27.9 \%$ of mothers had university and post graduate education. More over only $(5.4 \% \& 7.3 \%)$ of them were read and write Concerning occupation of their parents, the table estimated that $50 \%$ of student's fathers were employee, while $72.7 \%$ of their mothers were housewife and $61.1 \%$ of them live in rural area. the majority (93.8\%) of them had owned housing, $41.5 \%$ of family had income ranged between 1000 $<1800$; but only $(2.4 \%)$ of them had income $<300$. Also the result illustrated that $52.9 \%$ of students had middle socioeconomic class.
Figure (1): Clears total score of studied sample knowledge regarding fast food; it was illustrated that $40.0 \%$ of students had fair score of knowledge and $33.7 \%$ of them had poor score of knowledge, while (26.3\%)of them had good score of knowledge about fast food.

Figure (2): Reveals total score of studied sample attitude regarding fast food; it was cleared that $57.2 \%$ of students had positive attitude, while $42.8 \%$ of them had negative attitude toward fast food.

Figure (3): Clears that Correlation between the score of studied sample knowledge and attitude; which revealed a positive correlation among total score of student's knowledge and their attitude toward fast food $(\mathrm{r}=0.070 \& \mathrm{p}=0.014)$.

Table (2): Shows distribution of fast food consumption among students; it was illustrated that the majority $(91.9 \%)$ of students having fast food and 
$39.2 \%$ of them consuming it from 1-3 meals per week; also $59.9 \%$ of students consume fried potato as a most common types of fast food followed by $(59.4 \% \& 38.6 \%)$ of students consume pizza \&Grills respectively. Regarding reasons for having fast food $69.8 \%$ of students having it for save time. On the other hand $27.1 \%$ of students have ready to stay without fast food; $80.3 \%$ of them stated that they are ready to stay away from it because it is considered un healthy and the majority $(88.3 \%)$ of students eaten fast food with friends.

Table (3): Presents that relationship between studied sample knowledge, attitude and BMI regarding to fast food intake, which illustrated that there was statistical significant difference between students' knowledge, attitude and their having fast food ( $\mathrm{p}$ value $=(0.000)$. Moreover there was not statistical significant difference between student's BMI and their having fast food ( $\mathrm{p}$-value $=0.310)$.

Table (4): Illustrated the relationship between the studied sample knowledge, attitude and BMI regarding to fast food intake per week; it was found that there was statistical significant difference between students' knowledge, attitude and number of fast food meals per week (p-value $=0.000$ ), while there was not statistical significant difference between student's BMI and their number of fast food meals per week ( $p$-value $=0.334)$.

\section{Discussion}

Eating fast food is one of the bad habits that have increased among children, adolescents, and adults during the past three decades. The number of fast food outlets has increased intensely worldwide. Fast food is "designed for ready, availability use, or consumption with little consideration given to the quality or significance of food. It is time constrains, ease of access, quick service and convenience (Bailey et al., 2018).

The present study revealed that age of students mean was \pm SD $20.97 \pm 1.14$ with range $(18.0-25.0)$; this result similar with (El-Gilany \& Elkhawaga, 2012). Who carried study in El-Mansoura governorate, Egypt among university students who found their mean age was $20.2 \pm 1.7$ years with range 17-25.

Regarding to students sex, in the present study more than three fifths of students were males. This is congruent with( Al-Qahtani, 2016) who found that more than half of the students were males. While disagree with (Vibhute et al., 2018) who mentioned that more than three fifths of students were females. Also the finding disagree with (Mahmoud \& Taha , 2017) who stated that two thirds of their students were females.

Due to the fact that girls give more attention to the quality of food and due to girls care more about their body image than boys. while boys eating out the home with their peers more regularly because don't like to prepared food by themselves.

Regarding to the socioeconomic class of university students at the present study; more than half of students with middle socioeconomic class; this result disagreed with (El-Gilany \& Elkhawaga, 2012) who found that two thirds of the students have a high socioeconomic class.

Concerning fast food consumption among studied sample in the current study it was revealed that the majority of them had fast food and about more than one third consuming fast food meals between 13meals. This results similar with (Shaban, \& Alkazemi, 2019) who mentioned that more than one third of them eat fast food meal (1-2) per week. This finding disagrees with (Adams et al., 2015) who reported that studied sample eats outdoor every day during their study period.

In addition more than half of the studied sample consume fried potato and pizza as most common types of fast food .In this line, (Atinkut et al., 2018) who Found that commonest fast food consumed by college students were potatoes sandwich and pizza. Also the report of (El-Gilany \& Elkhawaga, 2012), which cleared that fast food are common among adolescent student in Egypt, and consumed fast food as pizza and potatoes sandwiches between meals.

This due to the studied sample were unconscious of the nutritional requirements to maintain a healthy body weight subsequently they can take poor nutritional decisions, which can cause poor weight management.

Concerning the reasons for eating fast food, it was revealed that more than three fifth of students eating fast food for save time. This result agree with, (Garcia et al., 2018) who cleared that more than three fifth of participants eating fast food for their occupied time (save time).In addition this finding consistent with(Goon, et al., 2014) who stated that three fifth considered the main reason for choosing fast food was save time., also agreed with (Hilger et al., 2017) who reported that half of students eating fast food because it saving time. On the other hand, This results disagreed with (Kanagamani, 2018) who stated that more than two thirds of them eating fast food because it was tasty.

This could be due to the busy study schedule and many students may go to far places, so they had to take fast foods as their lunch.

As regards the total score of students' knowledge toward fast food, the current study illustrated that two fifths of students had fair score of knowledge and one third of them had poor score of knowledge. Which consistent with( Abraham et al., 2016). Who found 
that the college students had a good level of knowledge regarding nutrition facts and health habits. The present study was cleared that more than half of studied sample had positive attitude toward fast food. This finding congruent with study by) Hu et al., 2016) who stated that university students had good attitude. Also, this finding was in the same line with (Akhter, 2019) who found that three fifth of the university students had a positive attitude toward fast food. However, (Pelletier et al., 2013) inconsistent with the current study who found that one third of the colleagues in USA had a low attitude level toward fast food.

The current study illustrated that there was statistical significant difference between student's knowledge and attitude with number of fast food meals per week. In this regard,) Lee \& Allen, 2020) concluded that, gender, mother's education and the frequency of eating out for breakfast were statistically associated with the scores of (knowledge, attitude and practice).

\section{Conclusion:}

The outcome of present study concluded that lack of students' knowledge and had positive attitude about fast food.

\section{Recommendations:}

1. Periodic health education programs regarding the effects of fast food on health.

2. Parents have to establish an example in front of their sons by not eating fast food and encourage home cooked food.

3. Communities, food companies and television should participate in promoting healthy food choices; the government should encourage advertisement of healthy food, which can generate interest among the people observers.

4. Further researches on effects of fast food on health.

\section{References:}

- Abraham, S., Noriega, B., \& Shin, J. (2016): College students eating habits and knowledge of nutritional requirements. Journal of Nutrition and Human Health, vol 2,No1:p45.

- Abd El-twab A. (2012): socioeconomic scale, faculty of Education, Assiut University.vol.31 No1pp31-68.

- Adams, J., Goffe, L., Brown, T., Lake, A., Summerbell, C., White, M., Wrieden, W., \& Adamson, A. (2015): Frequency and sociodemographic correlates of eating meals out and take-away meals at home: Cross-sectional analysis of the UK national diet and nutrition survey, waves 1-4 (2008-12). Int. J. Behav. Nutr. Phys. Act., 12, 51.

- Al-Qahtani M., (2016): Dietary Habits of Saudi Medical students at University of Dammam. International Journal of Health Sciences, Qassim University, Vol. 10, No. 3.p354.

- Akhter, M. (2019): Consumer Attitude toward Fast Food Consumption: A Study on University Students in Dhaka City. Asian Journal of Humanity, Art and Literature, vol 6 No1, pp2132.

- Atinkut, H., Tingwu, Y., Gebisa, B., Qin, S., Assefa, K., Yazie, B., \& Mirie, T. (2018): Factors influencing consumers choice of streetfoods and fast-foods in China. African Journal of Marketing Management, vol 10(4), pp28-39.

- Bailey, R., Fulgoni, V., Cowan, A., \& Gaine, P. (2018): Sources of added sugars in young children, adolescents, and adults with low and high intakes of added sugars. Nutrients, vol 10No(1),p 102.

- Barrett, M., Uí Dhuibhir, P., Njoroge, C., Wickham, S., Buchanan, P., Aktas, A., \& Walsh, D. (2020): Diet and nutrition information on nine national cancer organisation websites: A critical review. European Journal of Cancer Care, Vol 29No(5), p13280.

- El Ansari W., \& Samara A., (2018): Adherence to recommended dietary guidelines and the relationships with the importance of eating healthy in Egyptian university students. International Journal of Preventive Medicine ,vol 26 No 1pp9: 73

- El-Gilany A., \& Elkhawaga G. (2012): Socioeconomic determinants of eating pattern of adolescent students in Mansoura, Egypt. Pan Afr. Med. J.vol 15No(5), pp1:12.

- Egbujie, B., Delobelle, P., Levitt, N., Puoane, T., Sanders, D., \& van Wyk, B. (2018): Role of community health workers in type 2 diabetes mellitus self-management: A scoping review., vol13 No(6), p0198424.

- Garcia, M., Sato, P., Trude, A., Eckmann, T., Steeves, E., Hurley, K. \& Gittelsohn, J. (2018): Factors associated with home meal preparation and fast-food sources use among low-income urban African American adults. Ecology of food and nutrition, vol 57No (1), pp13-31.

- Goon, S., Bipasha, M., \& Islam, M. (2014): Fast food consumption and obesity risk among university students of Bangladesh. European Journal of Preventive Medicine, vol 2No(6), pp99-104.

- Hilger, J., Loerbroks, A., \& Diehl, K. (2017): Eating behaviour of university students in Germany: Dietary intake, barriers to healthy 
eating and changes in eating behaviour since the time of matriculation. Appetite, vol10 No 9, pp100-107.

- Hu, P., Huang, W., Bai, R., Zhang, F., Sharma, M., Shi, Z., \& Zhao, Y. (2016): Knowledge, attitude, and behaviors related to eating out among university students in China. International Journal of Environmental Research and Public Health, vol 13 No (7),p 696.

- Kanagamani, G. (2018): A Study to Evaluate the Effectiveness of Video Assisted Teaching Program on Knowledge and Practice regarding Fast Food related Health Hazards among Adolescent Boys from selected school at Madurai (Doctoral dissertation, CSI Jeyaraj Annapackiam College of Nursing, Madurai), p37.

- Kumari, R., \& Kumari M., (2020): Factors affecting the choice of fast food among teenagers of Sabour block in Bhagalpur district of India. The Pharma Innovation Journal.,vol 9No (10), pp211-216.

- Lee, J., \& Allen, J. (2020): Mother's educational attainment and their young adult daughters' fast food intake: The role of race/ethnicity. Health Care for Women International, vol $41 \mathrm{No}(2)$, pp169-187.

- Mahmoud, M., \& Taha, A. (2017): The association between eating habits and body mass index among nursing students. IOSR J Nurs Health Sci,vol 6, No 2pp14-26.

- Mackenbach. j., Charreire, H., (2018): Exploring the Relation of Spatial Access to Fast Food Outlets With Body Weight: A Mediation Analysis. Environment and Behavior,pp1-30.

- Monterrosa, E., Frongillo, E., Drewnowski, A., de Pee, S., \& Vandevijvere, S. (2020): Sociocultural influences on food choices and implications for sustainable healthy diets. Food and Nutrition Bulletin, vol 41(2_suppl), pp59-73.

- Musaiger A., Al-Haifi A., Al-Fayez M., AlAthari B., Al-Ajmi F., \& Al-Hazzaa H., (2013): Relative contribution of physical activity, sedentary behaviors, and dietary habits to the prevalence of obesity among Kuwaiti adolescents, Food \& Nutrition Bulletin, vol,34,No1,pp 6-13.

- Nipun, T., Debnath, D., Miah, M., Kabir, A., \& Hossain, M. (2017): Bangladeshi Student's Standpoint on Junk Food Consumption and Social Behaviour. IOSR Journal of Pharmacy and Biological Sciences, vol12 No(1), pp68-75.

- Palos Lucio, A., Sansores Martínez, D., Olvera Miranda, C., Quezada Méndez, L., \& Tolentino-Mayo, L. (2020): Nutritional Quality of Fast Food Kids Meals and Their Contribution to the Diets of School-Aged Children. Nutrients, vol1 2 No(3), p612.
- Pelletier, J., Laska, M., Neumark-Sztainer, D., \& Story, M. (2013): Positive attitudes toward organic, local, and sustainable foods are associated with higher dietary quality among young adults. Journal of the Academy of Nutrition and Dietetics,vol 113No(1), pp127-132.

- Shaban, L., \& Alkazemi, D. (2019): Trends in fast-food consumption among Kuwaiti youth. International Journal of Preventive Medicine, p10.

- Vibhute, N., Baad, R., Belgaumi, U., Kadashetti, V., Bommanavar, S., \& Kamate, W. (2018). Dietary habits amongst medical students: An institution-based study. Journal of family medicine and primary care, vol $7 \mathrm{No}(6)$, p1464.

- Yahya, f., \& Zafar, R., (2013): Trend of Fast Food Consumption and its Effect on Pakistani Society. Food Science and Quality Management. ,vol 11,pp2224-6088. 